\title{
Pathways for Water Loss from Doubly Protonated Peptides Containing Serine or Threonine
}

\author{
Alex G. Harrison \\ Department of Chemistry, University of Toronto, 80 St. George Street, Toronto, ON, M5S 3H6, Canada
}

\begin{abstract}
The doubly-protonated peptides Ala-Ala-Xaa-Ala-Ala-Ala-Arg show extensive loss of $\mathrm{H}_{2} \mathrm{O}$ when $\mathrm{Xaa}=\mathrm{Ser}$ or Thr. Using quasi-MS ${ }^{3}$ techniques the fragmentation reactions of the $\left[\mathrm{M}+2 \mathrm{H}-\mathrm{H}_{2} \mathrm{O}\right]^{+2}$ ions have been studied in detail. For both Ser and Thr, the $\left[\mathrm{M}+2 \mathrm{H}-\mathrm{H}_{2} \mathrm{O}\right]^{+2}$ ions show three primary fragmentation reactions, elimination of $\mathrm{CH}_{3} \mathrm{CH}=\mathrm{NH}$, elimination of one Ala residue, and elimination of two Ala residues, in all cases forming doubly-charged products. From a study of the further fragmentation of these products, it is concluded that elimination of two Ala residues results in formation of a three-membered aziridine ring by interaction with the adjacent amide function as $\mathrm{H}_{2} \mathrm{O}$ is lost. The elimination of one Ala residue results in formation of a five-membered oxazoline ring through interaction with the $\mathrm{N}$-terminal adjacent carbonyl function as $\mathrm{H}_{2} \mathrm{O}$ is lost. The elimination of $\mathrm{CH}_{3} \mathrm{CH}=\mathrm{NH}$ appears to involve formation of an eight-membered ring by interaction with the remote $\mathrm{N}$-terminal carbonyl function as $\mathrm{H}_{2} \mathrm{O}$ is lost. However, this initial structure undergoes rearrangement through interaction with the adjacent $\mathrm{C}$-terminal carbonyl function prior to further fragmentation. The $\left[\mathrm{MH}-\mathrm{H}_{2} \mathrm{O}\right]^{+}$ion of Ala-Ala-Ser-Ala-Ala-Ala also shows elimination of $\mathrm{CH}_{3} \mathrm{CH}=\mathrm{NH}$, one Ala residue and two Ala residues.
\end{abstract}

Key words: Quasi-MS ${ }^{3}$ studies, $\mathrm{H}_{2} \mathrm{O}$ loss, Tryptic type peptides, Doubly-charged species

\section{Introduction}

$\mathrm{T}$ andem mass spectrometry (MS/MS) has become a widely used method for deriving sequence information for peptides and proteins [1-3]. Commonly, such studies involve collision-induced dissociation (CID) of protonated or multiply-protonated peptides with sequence information being derived from the fragment ions observed. The important sequence-characteristic ions normally are $b$ and/or $y$ ions derived from cleavage of amide bonds in the peptide [4]. In addition to such sequence ions, non-sequence ions frequently are observed [4], particularly in low-energy CID [5]. These non-sequence ions often involve elimination of small neutral such as $\mathrm{H}_{2} \mathrm{O}$ or $\mathrm{NH}_{3}$ from the protonated species and/or from fragment ions.

A particularly common loss of $\mathrm{H}_{2} \mathrm{O}$ occurs for protonated peptides containing a serine or threonine residue where there

Correspondence to: Alex G. Harrison; e-mail: aharriso@chem.utoronto.ca is a side-chain hydroxyl group. Stein and co-workers [6] have observed substantial loss of water from doublyprotonated tryptic peptides containing a single Thr or Ser residue as the second or third residue (counting from the Nterminus) but a much reduced water loss when the Thr or Ser residue was further from the N-terminus. However, Wysocki and co-workers [7] have reported significant loss of water from doubly-protonated tryptic peptides containing serine, threonine, or homoserine in the fourth position. In recent work [8], we have observed major loss of water from the doubly-protonated peptides Ala-Ala-Xaa-Ala-Ala-Ala-Arg when Xaa is Ser or Thr.

Loss of water is observed for protonated serine and threonine [9]. Labeling of the carboxyl group with ${ }^{18} \mathrm{O}$ has shown $[10,11]$ that this loss involves the side-chain hydroxyl group. There have been several studies concerning the mechanism of water loss from protonated serine and threonine and their derivatives. For protonated serine and threonine, it has been shown that attack of the amino group 
in the hydroxyl-protonated form leads to water loss and formation of a protonated three-membered aziridine ring [12-14]. By contrast, in $\mathrm{N}$-acetyl derivatives interaction of the carboxyl group with the side-chain protonated hydroxyl group leads to formation of a protonated five-membered oxazoline ring upon loss of water [13]. The present paper reports a detailed study of the water loss fragmentation of doubly-protonated Ala-Ala-Xaa-Ala-Ala-Ala-Arg (Xaa=Ser and Thr). Evidence will be presented for several pathways for water loss including formation of a cyclic aziridine and a cyclic oxazoline.

\section{Experimental}

All experimental work was carried out using an electrospray/quadrupole/time-of-flight (QqTOF) mass spectrometer (QStarXL; MDS Sciex, Concord, Canada). All the present work involved determining product ion mass spectra following collisional activation for species that were fragment ions, so-called quasi-MS ${ }^{3}$ experiments. Collision-induced dissociation in the interface region produced fragment ions with those of interest being selected by the quadrupole mass analyzer $\mathrm{Q}$ followed by collisional activation in the quadrupole collision cell $\mathrm{q}$ and analysis of the ionic products with the time-of-flight
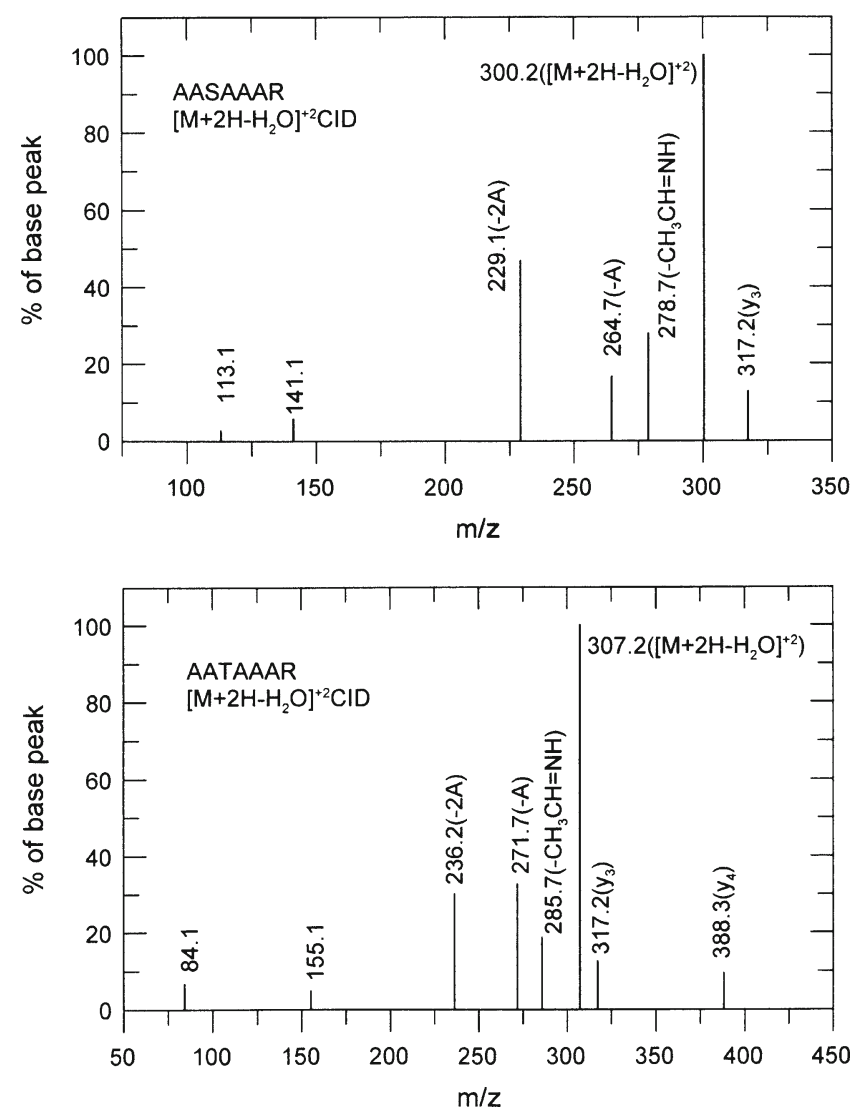

Figure 1. Product ion mass spectra for $\left[\mathrm{M}+2 \mathrm{H}-\mathrm{H}_{2} \mathrm{O}\right]^{+2}$ ions of Ala-Ala-Xaa-Ala-Ala-Ala-Arg for Xaa=Ser and Thr analyzer. The cone voltage in the interface region was adjusted, in each case, to give the best precursor ion signals; the spectra obtained were independent of the cone voltage.

Ionization was by electrospray. The peptide samples, at micromolar concentrations, were introduced into the electrospray source in 1:1 $\mathrm{CH}_{3} \mathrm{OH}$ : $1 \%$ aqueous formic acid by a syringe pump at a flow rate of $10 \mu \mathrm{L} \mathrm{min}$. Nitrogen was used as nebulizing and drying gas and as collision gas in the quadrupole collision cell. Doublycharged ion signals were identified by the half-mass separation of isotopic peaks. Typically, 60 to 70 scans were combined for each product ion mass spectrum to improve the signal-to-noise. With the exception of Figure 5, the results are presented as bar diagrams in the following. Isotopic peaks are not included nor are signals less than about $1 \%$ of the base peak, which could be due to system noise.

All peptide samples were obtained from Celtek Peptides (Nashville, TN); they showed no impurities in their mass spectra and were used as received.
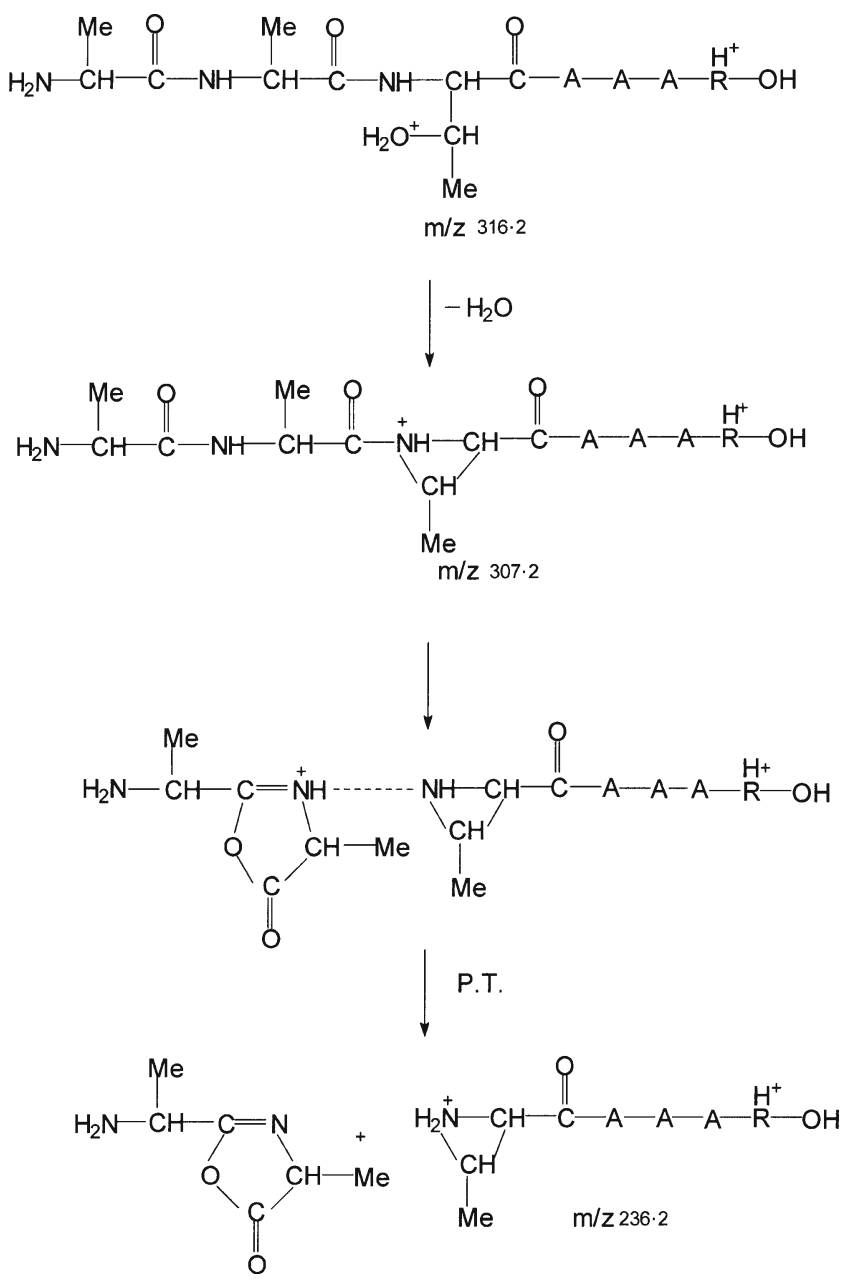

Scheme 1. Formation and fragmentation of aziridine on water loss 


\section{Results and Discussion}

\section{Water Loss from Doubly-Protonated Peptides}

As reported earlier [8], a major fragmentation reaction on collisional activation of doubly-protonated Ala-Ala-XaaAla-Ala-Ala-Arg when Xaa is Ser of Thr is elimination of neutral $\mathrm{H}_{2} \mathrm{O}$ to give the doubly-charged product $[\mathrm{M}+2 \mathrm{H}-$ $\left.\mathrm{H}_{2} \mathrm{O}\right]^{+2}$. Figure 1 shows the product ion mass spectra at $28 \mathrm{eV}$ collision energy (14 V applied collision voltage) for these ions when $\mathrm{Xaa}=\mathrm{Ser}$ (top) and Xaa=Thr (bottom). In each case, three doubly-charged products are observed corresponding, respectively, to elimination of $\mathrm{CH}_{3} \mathrm{CH}=\mathrm{NH}$, one Ala residue, and two Ala residues from the precursor ions. The singly-charged products observed at $\mathrm{m} / \mathrm{z}$ values of $317.2,141.1$, and 113.1 for $\mathrm{Xaa}=$ Ser and at $m / z$ values of $388.3,317.2155 .1$, and 84.1 for $\mathrm{Xaa}=\mathrm{Thr}$ arise, in each case, from further fragmentation of the $\left[\mathrm{M}+2 \mathrm{H}-\mathrm{H}_{2} \mathrm{O}-2 \mathrm{~A}\right]^{+2}$ product $(\mathrm{m} / z 229.1$ for Xaa=Ser and 236.2 for Xaa-Thr); the pathways to these products will be discussed in the following. At the lowest collision energies where further fragmentation was insignificant, the following approximate relative ion signals were recorded.

Ser: $m / z$ 278.7:m/z 264.7:m/z 229.1 $\approx 25: 13: 62$

Thr: $m / z$ 285.7:m/z 271.7:m/z 236.2 $\approx 18: 26: 56$
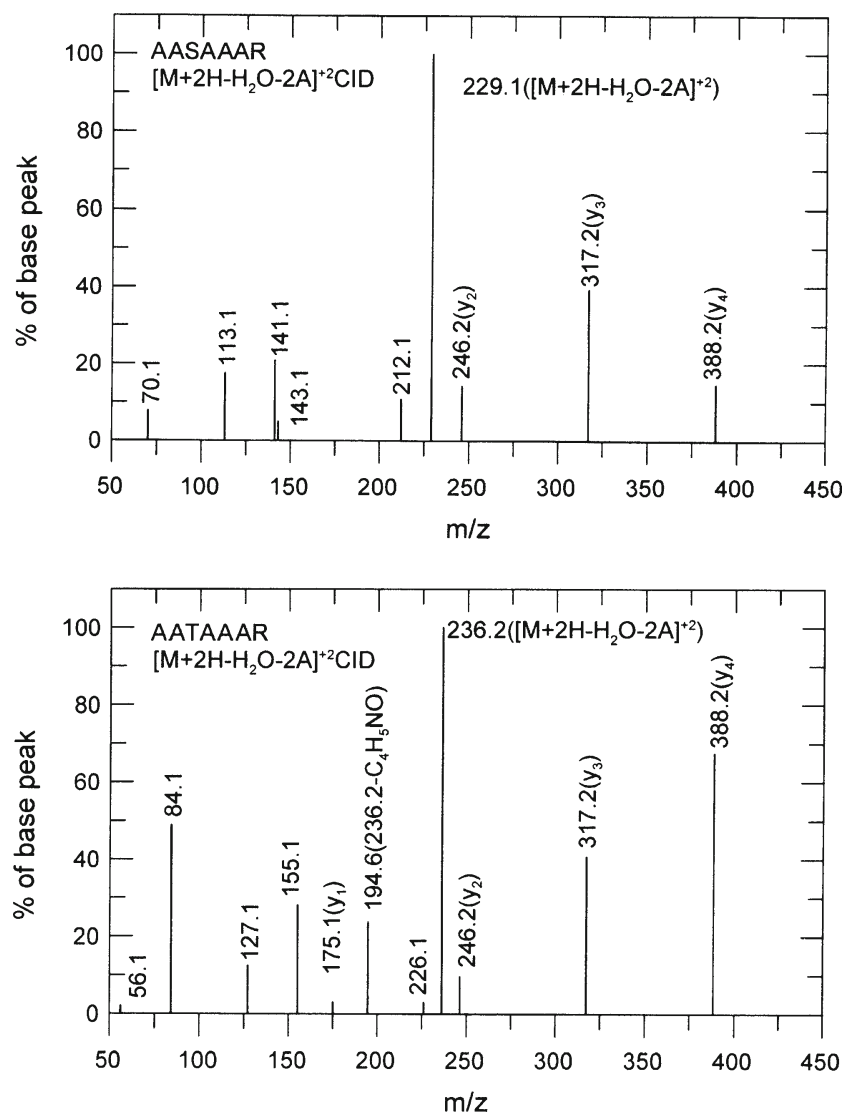

Figure 2. Product ion mass spectra for $\left[\mathrm{M}+2 \mathrm{H}-\mathrm{H}_{2} \mathrm{O}-2 \mathrm{~A}\right]^{+2}$ ions of Ala-Ala-Xaa-Ala-Ala-Ala-Arg for Xaa=Ser and Thr
The formation of the products corresponding to elimination of two Ala residues from $\left[\mathrm{M}+2 \mathrm{H}-\mathrm{H}_{2} \mathrm{O}\right]^{+2}$ can be readily rationalized in terms of formation of a threemembered aziridine ring in the initial water-loss reaction. This is illustrated in Scheme 1 for $\mathrm{Xaa}=\mathrm{Thr}$. (Throughout, "P.T." is used in the schemes as a short form for "proton transfer"). Initial loss of water involves, in this case, interaction of the amide nitrogen to form the protonated aziridine at $m / z 307.2$ (Thr) and $m / z 300.2$ (Ser) upon water loss. Upon collisional activation, these $\left[\mathrm{M}+2 \mathrm{H}-\mathrm{H}_{2} \mathrm{O}\right]^{+2}$ ions can eliminate two Ala residues as a neutral oxazolone to form the doubly-charged products at $\mathrm{m} / \mathrm{z} 236.2$ (Thr) and $\mathrm{m} / \mathrm{z}$ 229.1 (Ser), in both cases containing an aziridine ring at the N-terminus.

While Scheme 1, as drawn, proposes the involvement of an oxazolone ion and neutral, we cannot preclude the<smiles>CC(N)[Y]C(=O)C(C)N</smiles>

$\mathrm{m} / \mathrm{z} 155 \cdot 1$ $\mathrm{m} / \mathrm{z} 317 \cdot 2\left(\mathrm{y}_{3}\right)$<smiles>C[CH]C(=O)C(C)NC(=O)C(C)NC(=O)C1NC1C</smiles><smiles>[Te][Te]</smiles><smiles>[CH2+]NC(=O)C(C)NC(=O)C(C)NC(=O)C(C)N</smiles>
P.T.<smiles>CC(N)C(=O)NC(C)C(=O)C(C)NC(=O)C1NC1C</smiles><smiles>CC(N)C(=O)C(C)N</smiles>

Scheme 2. Fragmentation of $\left[\mathrm{M}+2 \mathrm{H}-\mathrm{H}_{2} \mathrm{O}-2 \mathrm{~A}\right]^{+2}$ ions 
possibility that the fragmentation involves diketopiperazine ion and neutral species rather than the oxazolone structures drawn. Theoretical calculations on the simplest system (i.e., glycine) indicate that the diketopiperazine $b_{2}$ neutral is ca. $17 \mathrm{kcal} \mathrm{mol}^{-1}$ more stable than the neutral oxazolone $\mathrm{b}_{2}$ structure [15]. Results have been presented [16, 17], which show that at least in some cases the neutral formed in the fragmentation of protonated tripeptides to form $\mathrm{y}_{1}$ ions have a diketopiperazine structure rather than an oxazolone structure. However, it also has been noted $[18,19]$ that formation of the diketopiperazine structure requires a trans $\rightarrow$ cis isomerization of the $\mathrm{N}$-terminal amide bond. This isomerization appears to be under kinetic control and is rather slow as a result. Thus, the structure of the neutral formed in Scheme 1 is not entirely clear.

Figure 2 presents the product ion mass spectra at $22 \mathrm{eV}$ collision energy for the $\left[\mathrm{M}+2 \mathrm{H}-\mathrm{H}_{2} \mathrm{O}-2 \mathrm{~A}\right]^{+2}$ ions for $\mathrm{Xaa}=$ Ser (top) and $\mathrm{Xaa}=\mathrm{Thr}$ (bottom). The major fragmentation modes are charge separation reactions to give $\mathrm{y}_{4}, \mathrm{y}_{3}$, and $\mathrm{y}_{2}$ ions and the corresponding N-terminal fragments at $m / z 84$, 155, and 226 for the Thr case and 14 mass units lower for the Ser case. The formation of the major products is rationalized in Scheme 2 using $\mathrm{Thr}$ as the example. A major fragmentation mode for the Thr case is charge separation to give the $\mathrm{y}_{4}$ ion and a product of $m / z$ 84. Although the structure shown in Scheme 2 for this product is unusual, theoretical calculations
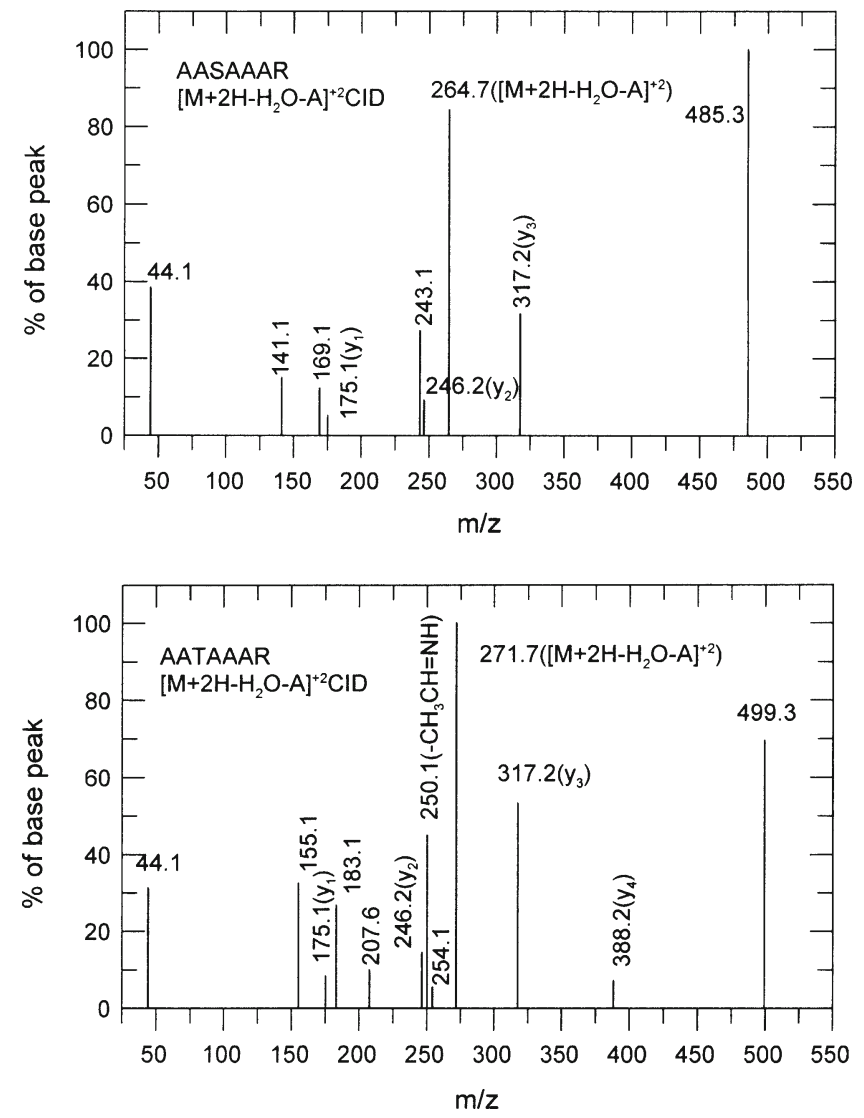

Figure 3. Product ion mass spectra for $\left[\mathrm{M}+2 \mathrm{H}-\mathrm{H}_{2} \mathrm{O}-\mathrm{A}\right]^{+2}$ ions of Ala-Ala-Xaa-Ala-Ala-Ala-Arg for Xaa=Ser and Thr
[B. Paizs, private communication] indicate that it is a stable species. Clearly, replacement of the methyl group in the aziridine ring by $\mathrm{H}$ makes this fragmentation pathway less favorable with respect to cleavage to give the $y_{3}$ ion and corresponding N-terminal fragment. Note that in the Thr case a doubly-charged fragment is observed at $\mathrm{m} / \mathrm{z} 194.6$ corresponding to elimination of a neutral $\mathrm{C}_{4} \mathrm{H}_{5} \mathrm{NO}$ species from $\left[\mathrm{M}+2 \mathrm{H}-\mathrm{H}_{2}-2 \mathrm{~A}\right]^{+2}$; this presumably originates by proton transfer from the incipient $\mathrm{m} / \mathrm{z} 84$ product to give $\mathrm{y}_{4}{ }^{+2}$. This fragmentation mode was not observed for the Ser case.

Figure 3 shows the product ion mass spectra at $28 \mathrm{eV}$ collision energy for the two $\left[\mathrm{M}+2 \mathrm{H}-\mathrm{H}_{2} \mathrm{O}-\mathrm{A}\right]^{+2}$ ions. Two
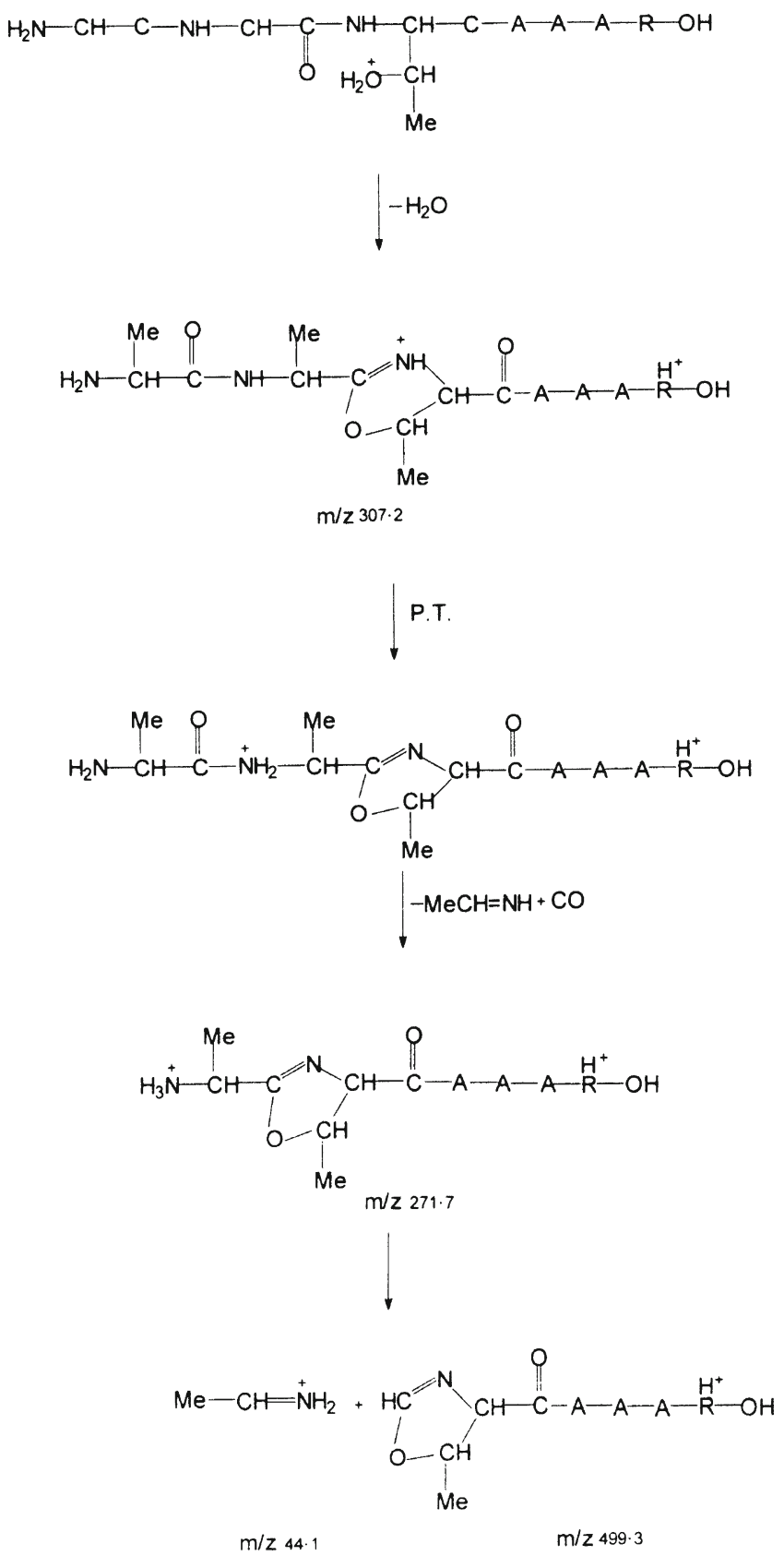

Scheme 3. Formation and fragmentation of oxazoline in water loss 
major fragmentation reactions are observed. Loss of neutral $\mathrm{CH}_{3} \mathrm{CH}=\mathrm{NH}$ leads to the doubly-charged ions at $m / z 243.1$ and 250.1 for Ser and Thr, respectively. A second major channel results in formation of the Ala iminium ion $\mathrm{CH}_{3} \mathrm{CH}=\mathrm{NH}_{2}{ }^{+}$at $\mathrm{m} / \mathrm{z} 44$ and the complementary charge-separation product observed at $\mathrm{m} / z 485.3$ (Ser) or $\mathrm{m} / \mathrm{z} 499.3$ (Thr). The remaining products originate by further fragmentation of the doubly-charged ions which result from elimination of $\mathrm{CH}_{3} \mathrm{CH}=\mathrm{NH}$. The formation and fragmentation of the $\left[\mathrm{M}+2 \mathrm{H}-\mathrm{H}_{2} \mathrm{O}-\mathrm{A}\right]^{+2}$ ions can be rationalized in terms of attack of the adjacent carbonyl function on the hydroxyl-protonated species and formation of a fivemembered oxazoline upon loss of $\mathrm{H}_{2} \mathrm{O}$, as illustrated in Scheme 3 for the Thr case. Subsequent loss of $\mathrm{CH}_{3} \mathrm{CH}=\mathrm{NH}+$ $\mathrm{CO}$ (i.e., an Ala residue) from this form of the $\left[\mathrm{M}+2 \mathrm{H}-\mathrm{H}_{2} \mathrm{O}\right]^{+2}$ ions leads to the doubly-charged ions observed (Figure 1) at $\mathrm{m} / \mathrm{z}$ 264.7 (Ser) and $\mathrm{m} / z 271.7$ (Thr). These latter ions can readily undergo charge separation on collisional activation to form $\mathrm{CH}_{3} \mathrm{CH}=\mathrm{NH}_{2}^{+}(\mathrm{m} / \mathrm{z} 44)$ and the corresponding high mass products at $m / z 485.3$ (Ser) and $m / z 499.3$ (Thr). Alternatively, as shown in Scheme 4, loss of neutral $\mathrm{CH}_{3} \mathrm{CH}=\mathrm{NH}$ from these species leads to the doubly-charged products at $\mathrm{m} / \mathrm{z} 243.1$ (Ser) or 250.1 (Thr). These latter species undergo fragmentation
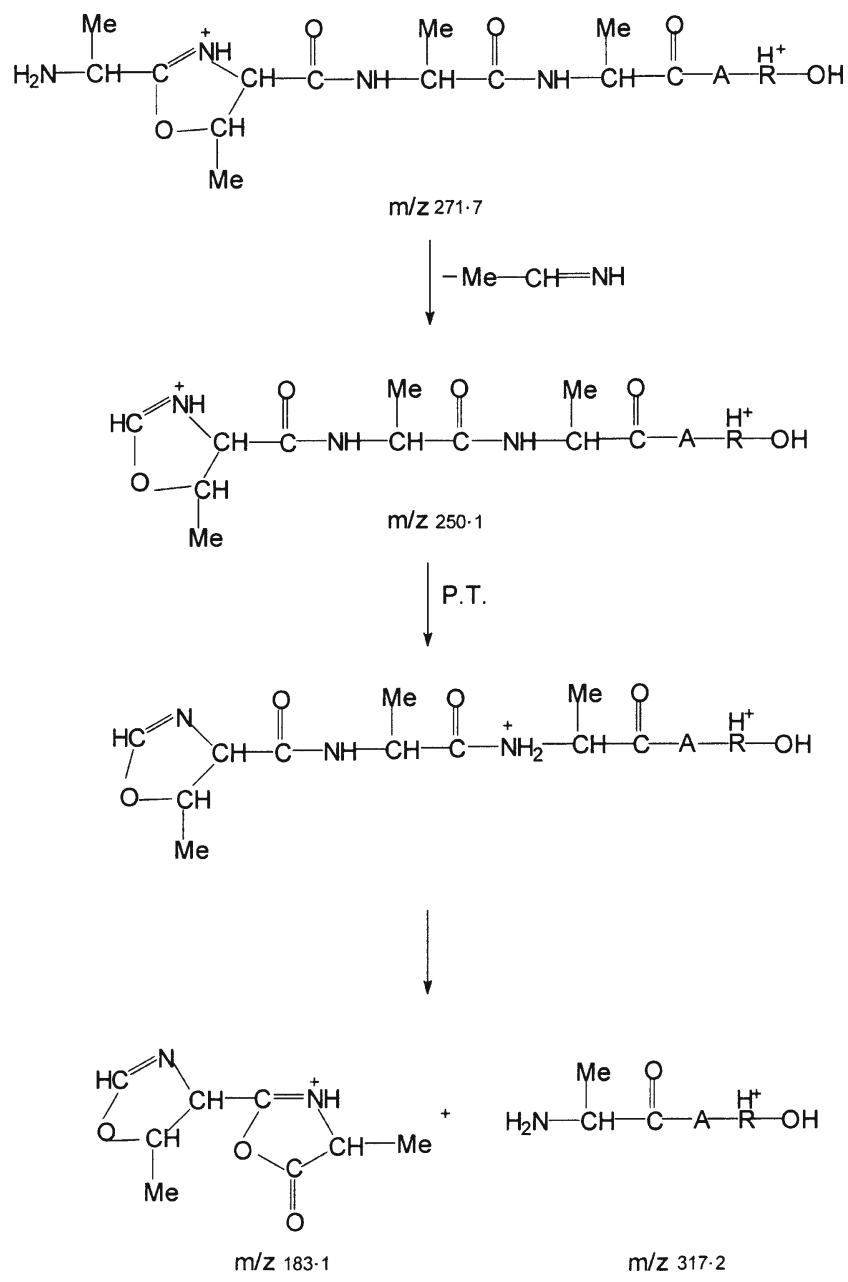

Scheme 4. Fragmentation of $\left[\mathrm{M}+2 \mathrm{H}-\mathrm{H}_{2} \mathrm{O}-\mathrm{A}\right]^{+2}$ ions primarily by charge separation to form the $\mathrm{y}_{3}$ ion $(\mathrm{m} / \mathrm{z} 317.2)$ and the lower mass products at $\mathrm{m} / \mathrm{z} 183.1$ (Thr) and $\mathrm{m} / \mathrm{z} 169.1$ (Ser); in both cases some loss of CO from these ions also is observed.

Figure 4 presents the product ion mass spectra for the $\left[\mathrm{M}+2 \mathrm{H}-\mathrm{H}_{2} \mathrm{O}-\mathrm{CH}_{3} \mathrm{CH}=\mathrm{NH}\right]^{+2}$ ions at $28 \mathrm{eV}$ collision energy. A major fragmentation mode is charge separation leading to formation of $\mathrm{m} / \mathrm{z} 44$ (actually, the unstable $\mathrm{H}_{2} \mathrm{NCH}\left(\mathrm{CH}_{3}\right) \mathrm{CO}^{+}$ion, which eliminates $\mathrm{CO}$ to give $\mathrm{CH}_{3} \mathrm{CH}=\mathrm{NH}_{2}{ }^{+}$as the observed ionic product [20]). The complementary ions are observed at $\mathrm{m} / \mathrm{z} 485.3$ (Ser) and $\mathrm{m} / z 499.3$ (Thr). Although these latter ions have the same $\mathrm{m} / \mathrm{z}$ values as the ionic products observed on charge separation of the $\left[\mathrm{M}+2 \mathrm{H}-\mathrm{H}_{2} \mathrm{O}-\mathrm{A}\right]^{+2}$ ions (Figure 3), they obviously have differing structures since substantial fragmentation by elimination of $\mathrm{H}_{2} \mathrm{O}$ and by elimination of $\mathrm{H}_{2} \mathrm{CO}$ (Ser) or $\mathrm{CH}_{3} \mathrm{CHO}$ (Thr) is observed only for the ions originating from the $\left[\mathrm{M}+2 \mathrm{H}-\mathrm{H}_{2} \mathrm{O}-\mathrm{CH}_{3} \mathrm{CH}=\mathrm{NH}\right]^{+2}$ precursors. A second major fragmentation mode is elimination of an Ala residue (presumably as $\mathrm{CH}_{3} \mathrm{CH}=\mathrm{NH}+\mathrm{CO}$ ) to form the doublycharged products at $\mathrm{m} / \mathrm{z} 243.1$ (Ser) and $\mathrm{m} / \mathrm{z} 250.1$ (Thr). Again, these products have the same $m / z$ values as the products observed in the fragmentation of the $\left[\mathrm{M}+2 \mathrm{H}-\mathrm{H}_{2} \mathrm{O}-\mathrm{A}\right]^{+2}$ ions (Figure 3) but the structures are clearly different since only the ions derived from $\left[\mathrm{M}+2 \mathrm{H}-\mathrm{H}_{2} \mathrm{O}-\mathrm{CH}_{3} \mathrm{CH}=\mathrm{NH}\right]^{+2}$ show
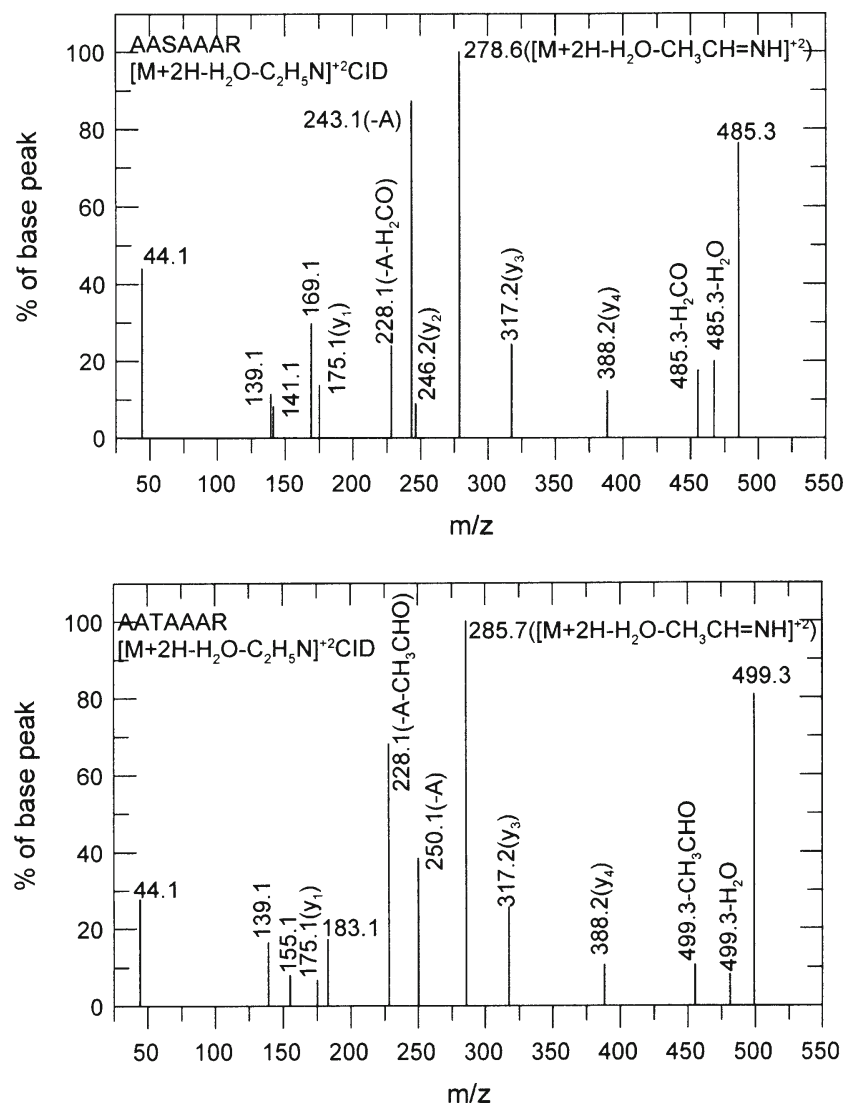

Figure 4. Product ion mass spectra for $\left[\mathrm{M}+2 \mathrm{H}-\mathrm{H}_{2} \mathrm{O}-\right.$ $\left.\mathrm{CH}_{3} \mathrm{CH}=\mathrm{NH}\right]^{+2}$ ions of Ala-Ala-Xaa-Ala-Ala-Ala-Arg for Xaa= Ser and Thr 
<smiles>CC(N)C(=O)NC(C)C(=O)NC(C(=O)NC(C)C(=O)O)C([O])O</smiles><smiles>CC1NC(C(C)N)NC(=O)C(C)OC(C(C)N)NC1=O</smiles>

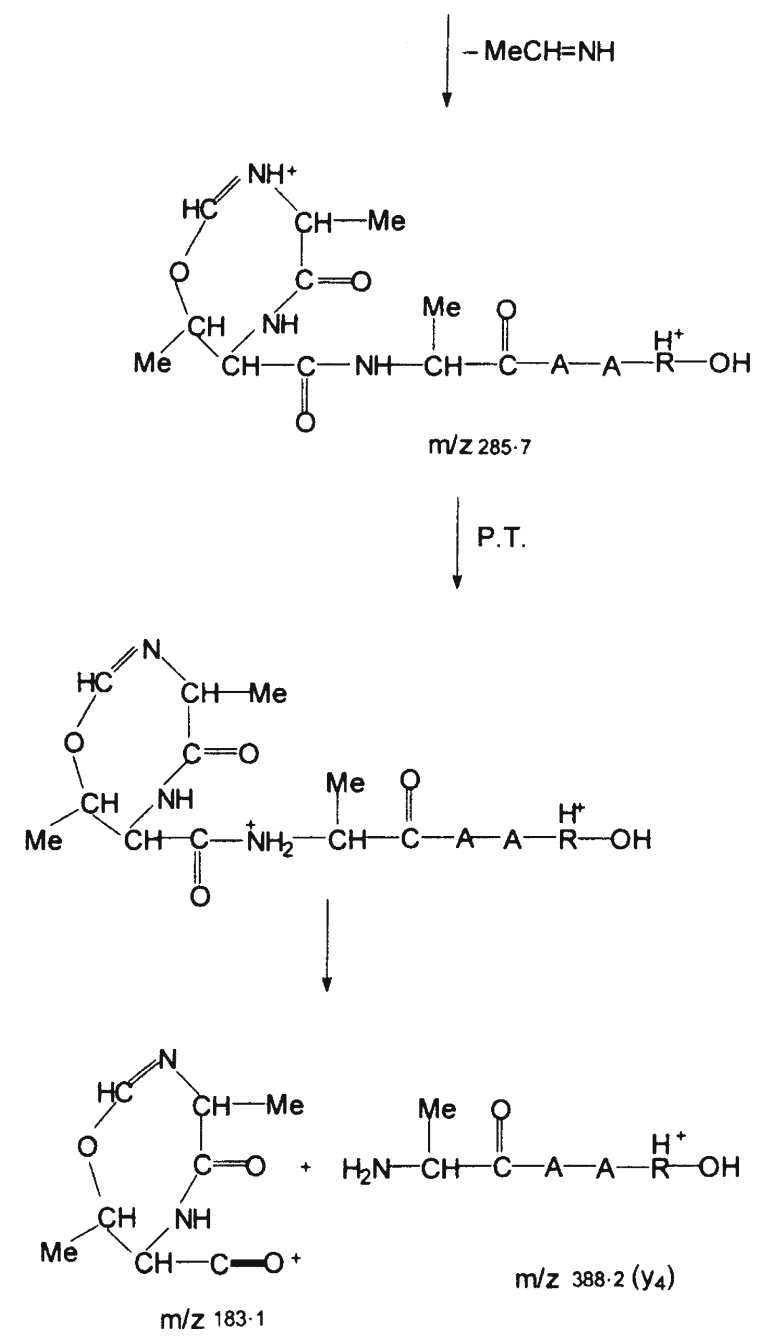

Scheme 5. Water loss leading to subsequent loss of $\mathrm{CH}_{3} \mathrm{CH}=\mathrm{NH}$ substantial elimination of $\mathrm{H}_{2} \mathrm{CO}$ (Ser) or $\mathrm{CH}_{3} \mathrm{CHO}$ (Thr) in further fragmentation.

The initial loss of $\mathrm{CH}_{3} \mathrm{CH}=\mathrm{NH}$ from the $\left[\mathrm{M}+2 \mathrm{H}-\mathrm{H}_{2} \mathrm{O}\right]^{+2}$ ions is most readily rationalized by interaction of the $\mathrm{N}$ terminal carbonyl function with the hydroxyl-protonated species to form an eight-membered cyclic structure upon elimination of $\mathrm{H}_{2} \mathrm{O}$, as illustrated in Scheme 5 for the Thr case. The $\left[\mathrm{M}+2 \mathrm{H}-\mathrm{H}_{2} \mathrm{O}-\mathrm{CH}_{3} \mathrm{CH}=\mathrm{NH}\right]^{+2}$ products, upon proton transfer, can fragment by charge separation to form the $\mathrm{y}_{4}$ ion $(\mathrm{m} / \mathrm{z} 388.2)$ and the corresponding lower mass products at $\mathrm{m} / \mathrm{z}$ 183.1 (Thr) or $m / z 169.1$ (Ser). This fragmentation channel is relatively minor, a major reaction being charge separation to form $\mathrm{m} / \mathrm{z} 44$ and the high-mass products at $\mathrm{m} / \mathrm{z} 485.3$ (Ser) and $\mathrm{m} / z 499.3$ (Thr). This fragmentation mode is most readily rationalized by rearrangement of the $\left[\mathrm{M}+2 \mathrm{H}-\mathrm{H}_{2} \mathrm{O}-\mathrm{CH}_{3} \mathrm{CH}=\right.$ $\mathrm{NH}]^{+2}$ ions as illustrated in Scheme 6 (again using the Thr example). The four-membered ring proposed as included in the high-mass products clearly can readily eliminate $\mathrm{CH}_{3} \mathrm{CHO}$ (Thr) or $\mathrm{H}_{2} \mathrm{CO}$ (Ser), as observed. Alternatively, if the
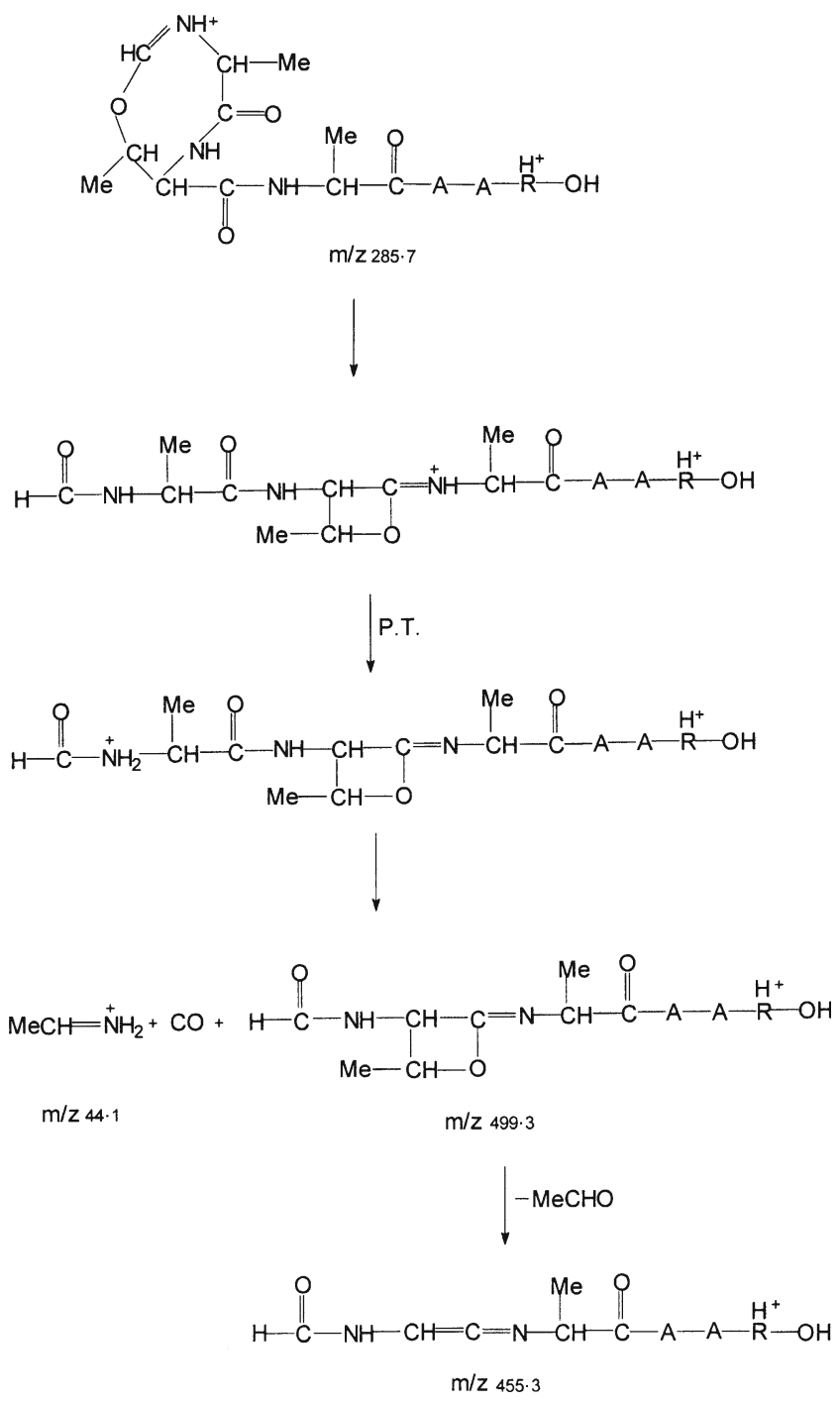

Scheme 6. Rearrangement and fragmentation of $[\mathrm{M}+2 \mathrm{H}-$ $\left.\mathrm{H}_{2} \mathrm{O}-\mathrm{CH}_{3} \mathrm{CH}=\mathrm{NH}\right]^{+2}$ 
rearranged $\left[\mathrm{M}+2 \mathrm{H}-\mathrm{H}_{2} \mathrm{O}-\mathrm{CH}_{3} \mathrm{CH}=\mathrm{NH}\right]^{+2}$ ions eliminate neutral $\mathrm{CH}_{3} \mathrm{CH}=\mathrm{NH}+\mathrm{CO}$, rather than $\mathrm{CH}_{3} \mathrm{CH}=\mathrm{NH}_{2}{ }^{+}+\mathrm{CO}$, the doubly-charged products at $\mathrm{m} / \mathrm{z} 250.1$ (Thr) and $\mathrm{m} / z 243.1$ (Ser) are produced, as illustrated in Scheme 7. Elimination of $\mathrm{CH}_{3} \mathrm{CHO}$ (Thr) or $\mathrm{H}_{2} \mathrm{CO}$ (Ser) gives the doubly-charged product at $\mathrm{m} / \mathrm{z} 228.1$, which, after proton migration, fragments by charge separation to give the products at $\mathrm{m} / \mathrm{z} 139.1$ and $\mathrm{m} / \mathrm{z}$ $317.2\left(\mathrm{y}_{3}\right)$. Alternatively, if the proton migration occurs prior to aldehyde elimination, charge separation leads to $\mathrm{m} / \mathrm{z} 317.2$ and the lower mass products at $\mathrm{m} / \mathrm{z} 183.1$ (Thr) or $\mathrm{m} / \mathrm{z} 169.1$ (Ser).

The present results show that the $\left[\mathrm{M}+2 \mathrm{H}-\mathrm{H}_{2} \mathrm{O}\right]^{+2}$ ions, which are major product ions in the fragmentation of the $[\mathrm{M}+2 \mathrm{H}]^{+2}$ ions, readily undergo fragmentation. This could lead to unexpected product ions in the CID mass spectra of the latter. For example, a product ion of $\mathrm{m} / \mathrm{z}$ 229 was noted in the product ion mass spectrum of the $[\mathrm{M}+2 \mathrm{H}]^{+2}$ ion of AASAAAR (see Figure 1 of Reference [8]). This product was not identified in the original publication but the present study (Figure 1) shows that this ion is, in fact, the $\left[\mathrm{M}+2 \mathrm{H}-\mathrm{H}_{2} \mathrm{O}-2 \mathrm{~A}\right]^{+2}$ fragment ion originating from further fragmentation of the $\left[\mathrm{M}+2 \mathrm{H}-\mathrm{H}_{2} \mathrm{O}\right]^{+2}$ initial product. Similarly, the product ion of $m / z 236$ in the CID spectrum of the $[\mathrm{M}+2 \mathrm{H}]^{+2}$ ion of AATAAAR (see Figure 1 of Reference [8]) was incorrectly identified as $\mathrm{y}_{5}{ }^{+2}-\mathrm{H}_{2} \mathrm{O}$ but is much more likely to be the $\left[\mathrm{M}+2 \mathrm{H}-\mathrm{H}_{2} \mathrm{O}-2 \mathrm{~A}\right]^{+2}$ ion (see Figure 1 of the present work).

Figure 5 shows the breakdown graph for the $[\mathrm{M}+2 \mathrm{H}]^{+2}$ ion of AASAAAR (only the major ions are shown). The results show that the $\left[\mathrm{M}+2 \mathrm{H}-\mathrm{H}_{2} \mathrm{O}\right]^{+2}(\mathrm{~m} / z$ 300.2) ion undergoes significant further fragmentation as the collision
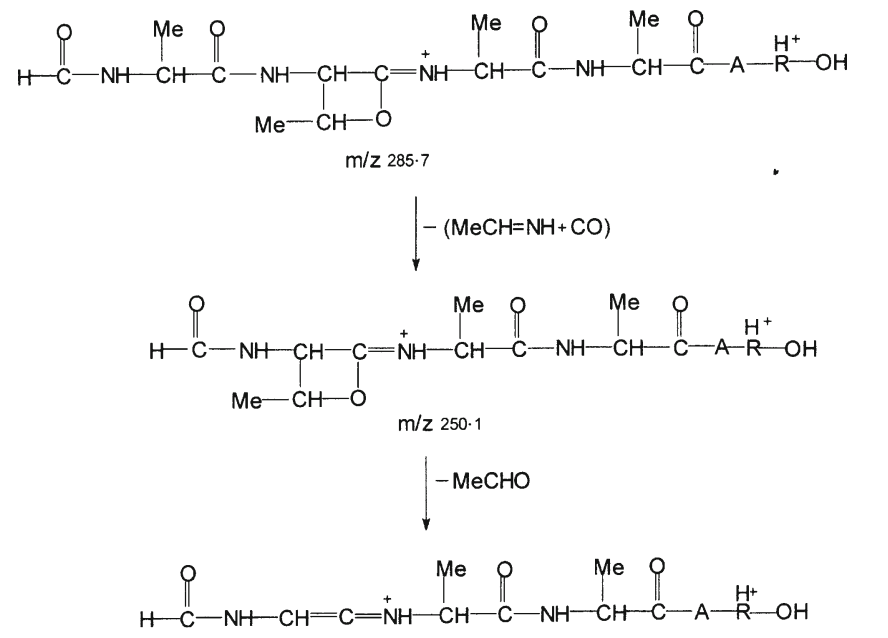

$\mathrm{m} / \mathrm{z} 228 \cdot 1$

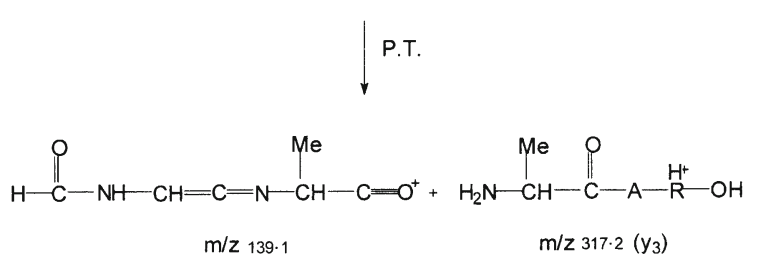

Scheme 7. Further fragmentation of $\left[\mathrm{M}+2 \mathrm{H}-\mathrm{H}_{2} \mathrm{O}-\right.$ $\left.\mathrm{CH}_{3} \mathrm{CH}=\mathrm{NH}\right]^{+2}$ ions

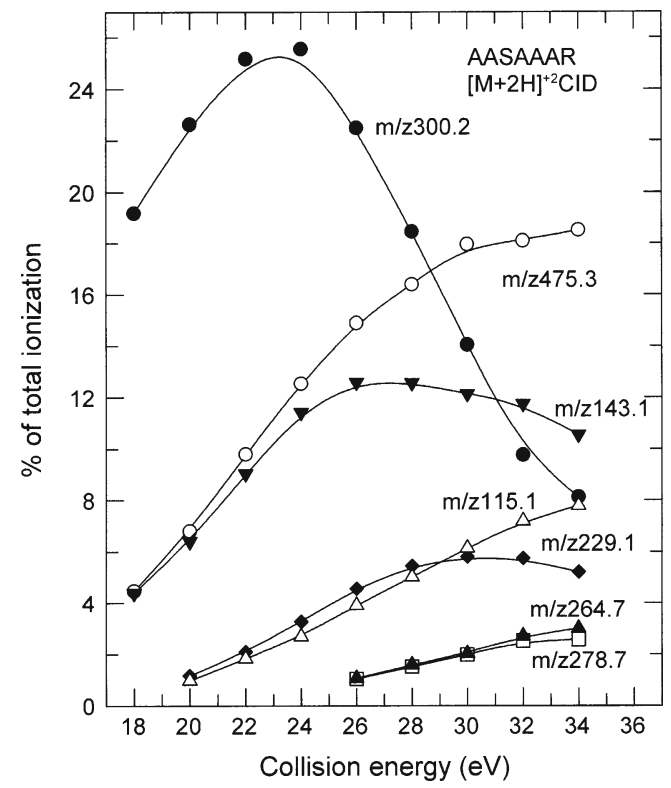

Figure 5. Breakdown graph for $[\mathrm{M}+2 \mathrm{H}]^{+2}$ ion of Ala-AlaSer-Ala-Ala-Ala-Arg. Minor signals at $m / z 388.3\left(\mathrm{y}_{4}\right), m / z 317.2$ $\left(\mathrm{y}_{3}\right)$, and $\mathrm{m} / \mathrm{z} 238.2\left(\mathrm{y}_{5}{ }^{+2}\right)$ (see Figure 1 of Reference [8]) have not been plotted

energy is increased. The primary fragmentation products of the $\mathrm{m} / \mathrm{z} 300.2$ species, i.e., $\mathrm{m} / \mathrm{z} 229.1,264.7$, and 278.7 are observed with significant abundance. This further fragmentation of the $\left[\mathrm{M}+2 \mathrm{H}-\mathrm{H}_{2} \mathrm{O}\right]^{+2}$ ions should be kept in mind when interpreting the CID mass spectra of doubly-charged tryptic peptides containing Ser or Thr.

\section{Water Loss from a Singly-Protonated Peptide}

The singly-protonated peptide Ala-Ala-Ser-Ala-Ala-Ala shows a weak signal in its product ion mass spectrum corresponding to elimination of $\mathrm{H}_{2} \mathrm{O}$. Figure 6 shows the product ion mass spectrum at $22 \mathrm{eV}$ collision energy for this $\left[\mathrm{MH}-\mathrm{H}_{2} \mathrm{O}\right]^{+}$ion. A major fragmentation route involves initial loss of H-Ala-OH to form a $b_{5}$ ion followed by

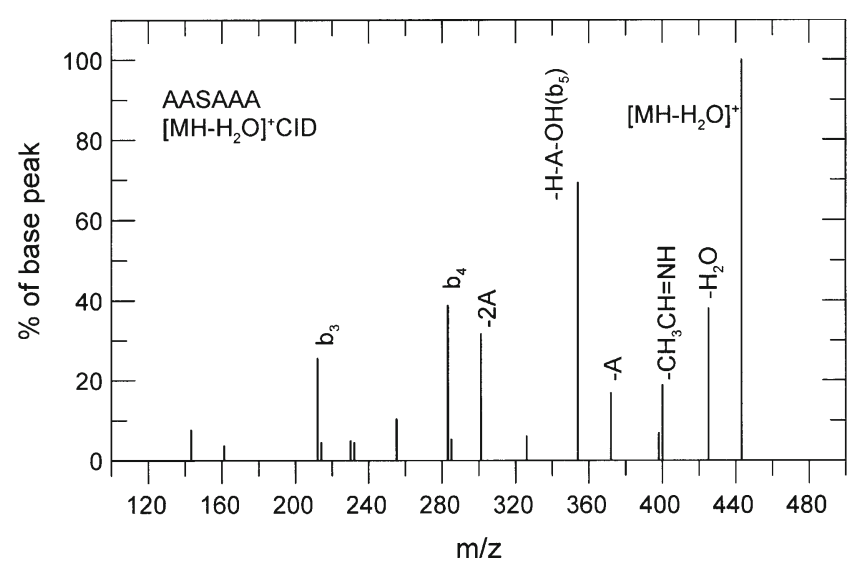

Figure 6. Product ion mass spectrum for the $\left[\mathrm{MH}-\mathrm{H}_{2} \mathrm{O}\right]^{+}$ion derived from Ala-Ala-Ser-Ala-Ala-Ala 
successive loss of two Ala residues to give $b_{4}$ and $b_{3}$ ions. In addition, there are significant signals corresponding to loss of $\mathrm{CH}_{3} \mathrm{CH}=\mathrm{NH}$, loss of one Ala residue, and loss of two Ala residues from the $\left[\mathrm{MH}-\mathrm{H}_{2} \mathrm{O}\right]^{+}$ion. The distribution of these neutral losses is similar to the distribution of neutral losses from the $\left[\mathrm{M}+2 \mathrm{H}-\mathrm{H}_{2} \mathrm{O}\right]^{+2}$ ion of Ala-Ala-Ser-AlaAla-Ala-Arg (Figure 1), suggesting that a similar distribution of structures is formed in both cases on $\mathrm{H}_{2} \mathrm{O}$ elimination. Unfortunately, the signals for these fragmentation products were too weak in the singly charged case to obtain reliable product ion mass spectra.

\section{Conclusions}

The present study presents strong evidence for three pathways for $\mathrm{H}_{2} \mathrm{O}$ elimination from doubly-protonated Ala-AlaXaa-Ala-Ala-Ala-Arg when Xaa=Ser or Thr. One pathway (Scheme 1) leads to formation of an aziridine ring on water loss. This pathway has been shown to be operative in loss of $\mathrm{H}_{2} \mathrm{O}$ from protonated serine and threonine [12-14]. A second pathway involves (Scheme 3) formation of an oxazoline upon elimination of $\mathrm{H}_{2} \mathrm{O}$. This pathway has been shown to be operative in the elimination of $\mathrm{H}_{2} \mathrm{O}$ from protonated $N$-acetylserine [13]. Indeed, Reid et al. [13] have concluded from $a b$ initio calculations on the fragmentation of protonated $N$-acetylserine that the pathway leading to the five-membered oxazoline ring has a considerably lower transition state energy than the pathway leading to the threemembered aziridine ring. Such does not appear to be the case for the larger systems studied in the present work.

An unexpected result was the observation of the loss of $\mathrm{CH}_{3} \mathrm{CH}=\mathrm{NH}$ from the $\left[\mathrm{M}+2 \mathrm{H}-\mathrm{H}_{2} \mathrm{O}\right]^{+2}$ species. This would appear to involve interaction with the remote $\mathrm{N}$ terminal carbonyl function as illustrated in Scheme 5 . However, it is very evident that rearrangement as shown in Scheme 6 must occur to rationalize the major fragmentation reactions which follow elimination of $\mathrm{CH}_{3} \mathrm{CH}=\mathrm{NH}$.

The extent of water loss by each of the routes elucidated in the present study is very similar for the Ser and Thr peptides. Clearly, the extent of water elimination by each route would be expected to depend on the position of the Ser or Thr residue in the peptide. This aspect has not been explored in the present work.

\section{Acknowledgments}

The author is indebted to the Natural Sciences and Engineering Research Council (Canada) for continued financial support. Dr. B. Paizs is thanked for helpful discussions, particularly with respect to theoretical matters.

\section{References}

1. Larsen, M.R., Roepstorff, P.: Mass Spectrometric Identification of Proteins and Characterization of Their Post-Translational Modifications in Proteome Analysis. Fresenius J. Anal. Chem. 366, 677-690 (2000)

2. Aebersold, R., Goodlett, D.R.: Mass Spectrometry in Proteomics. Chem. Rev. 101, 269-295 (2001)

3. Medzihradszky, K.F.: Peptide Sequence Analysis. Methods Enzymol 402, 209-244 (2005)

4. Paizs, B., Suhai, S.: Fragmentation Pathways of Protonated Peptides. Mass Spectrom. Rev. 24, 508-548 (2005)

5. Pappayannopoulos, I.A.: The Interpretation of Collision-Induced Dissociation Tandem Mass Spectra of Peptides. Mass Spectrom. Rev. 14, 49-73 (1995)

6. Neta, P., Pu, Q.-L., Yang, X., Stein, S.E.: Consecutive Neutral Losses of $\mathrm{H}_{2} \mathrm{O}$ and $\mathrm{C}_{2} \mathrm{H}_{4} \mathrm{O}$ from N-Terminal Thr-Thr and Thr-Ser in CollisionInduced Dissociation of Protonated Peptides. Position Dependent Water Loss from Single Thr or Ser. Int. J. Mass Spectrom. 267, 295-301 (2007)

7. Zhang, Q., Perkins, B., Tan, G., Wysocki, V.H.: The Role of Proton Bridging in Selective Cleavage of Ser-, Thr-, Cys-, Met-, Asp-, and Asn-Containing Peptides. Int. J. Mass Spectrom. 300, 108-117 (2011)

8. Harrison, A.G.: Effect of the Identity of Xaa on the Fragmentation Modes of Doubly-Protonated Ala-Ala-Xaa-Ala-Ala-Ala-Arg. J. Am. Soc. Mass Spectrom. 22, 906-911 (2011)

9. Dookeran, N.N., Yalcin, T., Harrison, A.G.: Fragmentation Reactions of Protonated $\alpha$-Amino Acids. J. Mass Spectrom. 31, 500-509 (1996)

10. Van Dongen, W.D., de Koster, C.G., Heerma, W., Haverkamp, J.: The Diagnostic Value of the $m / z 102$ Peak in Fast-Atom Bombardment Mass Spectra of Peptides. Rapid Commun. Mass Spectrom. 9, 845-850 (1995)

11. Ballard, K.D., Gaskell, S.J.: Dehydration of Peptide $[\mathrm{M}+\mathrm{H}]^{+}$Ions in the Gas Phase. J. Am. Soc. Mass Spectrom. 4, 477-481 (1993)

12. O'Hair, R.A.J., Reid, G.E.: Does Side Chain Water Loss from Protonated Threonine Yield N-Protonated Dehydroamino-2-Butyric Acid? Rapid Commun. Mass Spectrom. 12, 999-1002 (1998)

13. Reid, G.E., Simpson, R.J., O'Hair, R.A.J.: Leaving Group and Gas Phase Neighboring Group Effects in the Side Chain Losses from Protonated Serine and its Derivatives. J. Am. Soc. Mass Spectrom. 11, 1047-1060 (2000)

14. Serafin, S.V., Zhang, K., Aurelio, L., Hughes, A.B., Morton, T.H.: Decomposition of Protonated Threonine, Its Stereoisomers, and Its Homologues in the Gas Phase: Evidence for Internal Backside Displacement. Org. Lett. 6, 1561-1564 (2004)

15. Chass, G.A., Marai, C.N.J., Setiadi, D.H., Csizmadia, I.G., Harrison, A. G.: A Hartree-Fock, MP2 and DFT Computational Study of the Structures and Energies of " $b_{2}$ Ions Derived from Deprotonated Peptides. A Comparison of Method and Basis Set Used on Relative Product Stabilities. J. Molec. Struct. (Theochem) 675, 149-162 (2004)

16. Cordero, M.M., Houser, J.J., Wesdemiotis, C.: The Neutral Products Formed During Fragmentation of Protonated Peptides in Tandem Mass Spectrometry. Anal. Chem. 65, 1594-1601 (1993)

17. Nold, M.J., Wesdemiotis, C., Yalcin, T., Harrison, A.G.: Amide Bond Dissociation in Protonated Peptides. Structures of the N-terminal Ionic and Neutral Fragments. Int. J. Mass Spectrom. Ion Processes 164, 137152 (1997)

18. Paizs, B., Suhai, S.: Combined Quantum Chemical and RRKM Modeling of the Main Fragmentation Pathways of Protonated GGG. 1. Cis-trans Isomerization Around Amide Bonds. Rapid Commun. Mass Spectrom. 15, 2307-2323 (2001)

19. Paizs, B., Suhai, S., Harrison, A.G.: Experimental and Theoretical Investigation of the Main Fragmentation Pathways of Protonated HGly-Gly-Sar-OH and H-Gly-Sar-Sar-OH. J. Am. Soc. Mass Spectrom. 14, 1454-1469 (2003)

20. Harrison, A.G.: To b or not to b. The Ongoing Saga of Peptide b Ions. Mass Spectrom. Rev. 28, 640-654 (2009) 